\title{
Dietary soya protein during pregnancy and lactation in rats with hereditary kidney disease attenuates disease progression in offspring $\dagger$
}

\author{
Leah E. Cahill ${ }^{1}$, Claudia Yu-Chen Peng ${ }^{1}$, Neda Bankovic-Calic ${ }^{2}$, Deepa Sankaran ${ }^{1}$, \\ Malcolm R. Ogborn ${ }^{1,2,3}$ and Harold M. Aukema ${ }^{1,3 *}$ \\ ${ }^{1}$ University of Manitoba, Department of Human Nutritional Sciences, Winnipeg, Manitoba R3T 2N2, Canada \\ ${ }^{2}$ University of Manitoba, Department of Pediatrics and Child Health, Winnipeg, Manitoba R3A 1S1, Canada \\ ${ }^{3}$ Manitoba Institute of Child Health, Winnipeg, Manitoba R3E 3P4, Canada
}

(Received 8 March 2006 - Revised 5 July 2006 - Accepted 4 August 2006)

\begin{abstract}
Dietary soya protein substitution for casein initiated at weaning slows disease progression in animal models of chronic renal disease. As there is increasing evidence that fetal programming can have a significant impact on kidney physiology and function in offspring, the objective of the current study was to determine whether exposure to soya protein in the diet earlier than weaning would have further benefits. Han:SPRD-cy $(c y /+)$ breeder rats were fed a casein-based or soya protein-based diet 2 weeks prior to mating, throughout pregnancy and during lactation. Following this maternal period, 3-week-old pups were given either the same or the alternate diet for a 7-week weaning period. Dietary soya protein compared with casein in the maternal or weaning period both independently resulted in less renal inflammation (macrophage infiltration lower by $24 \%(P=0.0003)$ and $32 \%(P<0.0001)$, respectively). When soya protein was given in both feeding periods, the effect was additive. Soya protein substitution for casein resulted in less oxidative damage as indicated by $28 \%$ lower oxidized-LDL staining $(P=0.013)$ when present in the maternal period, or in the weaning period (by $56 \%, P<0.0001)$. Renal cell proliferation was reduced by $29-33 \%(P<0.05)$ in rats given soya protein whether the exposure was during the maternal or weaning period. Soya protein compared with casein in the maternal period also resulted in $33 \%(P=0.0013)$ less proteinuria, indicating superior renal function. Dietary soya protein during pregnancy and lactation represents a potential preventative approach in treating for those with congenital kidney diseases.
\end{abstract}

Soya protein: Kidney disease: Maternal nutrition: Rats

The worldwide rise in patients with chronic kidney disease and consequent end-stage renal failure is threatening to reach epidemic proportions over the next decade (Meguid el Nahas \& Bello, 2005). Hence, treatments that are effective at delaying the progression of kidney disease have potential to reduce death rates. Dietary protein restriction is an effective strategy to slow kidney disease advancement (Hostetter, 2003). Unfortunately, dietary protein restriction is difficult for many to achieve and may increase the risk of protein malnutrition. This is particularly important in the latter stages of renal disease and during the early life stages of pregnancy, lactation and childhood. Therefore, as an alternative to dietary protein restriction, there is interest in determining whether protein source differentially affects kidney disease progression.

Protein intake from non-animal sources is associated with attenuation in the decline of renal function in individuals with mild renal insufficiency (Knight et al. 2003). Dietary manipulation with a vegetarian soya diet for as little as 8 or 16 weeks in nephrotic patients decreases proteinuria and vegetarians exhibit lower glomerular filtration rates than omnivores (Bosch et al. 1983; Kontessis et al. 1990; Barsotti et al. 1991; D'Amico et al. 1991; Gentile et al. 1993). In diabetic patients, soya protein interventions have been shown to reduce glomerular hyperfiltration, proteinuria or albuminuria (Jibani et al. 1991; Azadbakht et al. 2003; Teixeira et al. 2004; Stephenson et al. 2005). Due to practical limitations, however, human studies to date have been of short duration and have not examined the effects of soya protein on renal histological damage. Longer-term studies and studies beginning in the earlier stages of renal disease have therefore been restricted to animal models. In these studies, soya protein compared with casein is recognized as having beneficial effects on chronic renal injury and disease progression. Such models include $\mathrm{db} / \mathrm{db}$ mice with type 2 diabetic nephropathy (Teixeira et al. 2003), five-sixths nephrectomized Wistar rats (Williams \& Wallis, 1987a,b; Chen et al. 2003), Wistar rats with chronic nephrotic syndrome (Pedraza-Chaverri et al. 2004), aging Fischer 344 rats (Iwasaki et al. 1988) and models of genetically determined cystic renal diseases such as pcy mice (Tomobe et al. 1998; Aukema et al. 1999) and the Han:SPRD-cy rat (Ogborn et al. 1998, 2000; Aukema \& Housini, 2001; Fair et al. 2004).

Cystic renal diseases are common renal disorders that are primarily genetically determined, occurring in one in 500 to 1000 individuals, regardless of ethnic origin. The pathology of renal cystic diseases ultimately resembles other forms of chronic

* Corresponding author: Harold Aukema, fax +204 474 7593, email Aukema@UManitoba.CA

$\dagger$ Presented in part in abstract form at the 6th International Symposium on the Role of Soy Protein in Preventing and Treating Chronic Disease, October 2005. 
renal disease and injury, including increases in interstitial inflammation, fibrosis, oxidative damage and cell proliferation (Zerres et al. 1984). The Han:SPRD-cy rat model of renal cyst disease is an excellent model for exploring potential preventative and therapeutic strategies to slow renal disease progression and modify renal damage (Cowley et al. 1993; Gretz et al. 1995). Feeding soya protein to Han:SPRD-cy rats from weaning for as short a time period as 1 week reduces renal fibrosis (Fair et al. 2004), and longer exposure (6-8 weeks) of weanling rats to soya protein reduces cyst growth, renal inflammation and serum creatinine levels (Ogborn et al. 1998, 2000; Aukema \& Housini, 2001). We hypothesized that dietary soya protein in the maternal period would delay the progression of renal disease in offspring in the Han:SPRD-cy rat model of kidney disease.

\section{Methods}

\section{Animals and diet}

Han:SPRD-cy (also known as $\mathrm{PKD} / \mathrm{Mhm}(\mathrm{cy} /+)$ ) rats were derived from our breeding colony, which originated from the colony of Dr. Benjamin Cowley, University of Kansas Medical Center, Kansas City, KS, USA (Cowley et al. 1993). All animal procedures were in accordance with the guidelines of the Canadian Council on Animal Care. Sixteen breeder Han:SPRD-cy rat pairs were randomly assigned to each of the treatment (soya protein isolate) or control (casein) diets 2 weeks prior to mating and continued with these diets during pregnancy and lactation (maternal period). The number of litters successfully delivered (thirteen for treatment group, fourteen for control group), litter size and pup survival in each treatment diet were similar. Surviving male pups were weaned at 3 weeks of age and randomly assigned to either the treatment or control diet for 7 more weeks (weaning period). This resulted in a $2 \times 2$ study design that assesses the effect of maternal period (casein or soya protein) and weaning period (casein or soya protein) in four groups of rats (casein/casein; casein/soya protein; soya protein/casein; soya protein/soya protein). At termination, heterozygous rats were identified and used for the current analyses, resulting in fifty-four $c y /+$ rats. Male rats were used because this disease progresses more rapidly in male animals and thus would be more likely to be affected by therapeutic interventions (Cowley et al. 1993). Diet ingredients were purchased from Dyets Inc. (Bethlehem, PA, USA) and Harlan Teklad (Madison, WI, USA). Diets were based on the AIN93G guidelines for rodent diets (American Institute of Nutrition, 1993), with the only differences being that maize oil was used instead of soyabean oil as the lipid source in both diets and that an equivalent amount of protein in the form of a heat-treated soya protein isolate (Dyets Inc.) replaced the casein in the soya protein diet (Table 1). Rats were weighed weekly and at termination. Food and water intakes were determined at 3 and 6 weeks of the weaning period. Prior to termination, the rats were placed in metabolic cages for a period of $24 \mathrm{~h}$ to collect urine. At termination, rats were anaesthetized by $\mathrm{CO}_{2}$ overexposure and killed by decapitation to facilitate collection of trunk blood and the rapid removal of tissues.

\section{Histology}

Upon termination, kidneys were removed, weighed, fixed in $10 \%$ buffered formalin and embedded in paraffin. Sections
Table 1. Nutrition composition of experimental diets*

\begin{tabular}{lcc}
\hline Ingredient & $\begin{array}{c}\text { Casein } \\
(\mathrm{g} / \mathrm{kg})\end{array}$ & $\begin{array}{c}\text { Soya protein } \\
(\mathrm{g} / \mathrm{kg})\end{array}$ \\
\hline Maize starch & $397 \cdot 486$ & $397 \cdot 486$ \\
Casein $(87 \%)$ & 200 & - \\
Soya protein $(87 \cdot 1 \%)$ & - & 200 \\
Dextrinized maize starch & 132 & 132 \\
Sucrose & 100 & 100 \\
Maize oil† & 70 & 70 \\
Cellulose & 50 & 50 \\
Mineral mix (AIN 93G) & 35 & 35 \\
Vitamin mix (AIN 93 VX) & 10 & 10 \\
L-cystine & 3 & 3 \\
Choline bitartrate & $2 \cdot 5$ & $2 \cdot 5$ \\
Totalł & 1000 & 1000 \\
\hline
\end{tabular}

${ }^{*}$ For details of diets and procedures, see pp. 78-79.

† Contains $0.02 \%$ tert-butylhydroqunone.

$\ddagger$ Casein and soya protein diets, respectively, provided minerals in the following amounts (mg/kg diet): $\mathrm{Na} 1039$ and 2819; K 3610 and 3800; P 3061 and 3161; Ca, 5100 and 5400.

$(5 \mu \mathrm{m})$ were cut from the bisected face of the kidneys, producing consistent representative sections from each animal that were then mounted on slides. At least fifty randomly selected image fields were analysed for morphological and histological analyses from one slide per kidney. The sections were stained with haematoxylin and eosin to measure cyst area and with Sirius red for quantitative analysis of fibrosis as previously described (Ogborn et al. 1998, 2000, 2005). The latter staining permits image analysis measurement using a standard incandescent microscope light source. A blinded observer (N.B.C.) classified the animals as diseased or normal on the basis of cyst growth and pathology that is characteristic of the disease.

\section{Immunohistochemistry}

Renal inflammation was detected using a 1:50 dilution of a monoclonal antibody against the equivalent of the human CD68 antigen (MAB 1435; Chemicon International, Temeculca, CA, USA). Oxidant injury was measured by identifying oxidized LDL, using a rabbit polyclonal antibody against $\mathrm{Cu}$ oxidized human LDL (AB3230; Chemicon International). Renal cell proliferation was detected using a 1:50 dilution of an anti-mouse proliferating cell nuclear antigen antibody (M0879; Dako Corporation, Carpinteria, CA, USA). The Dako EnVision Plus System (K4008; Dako Corporation) was used for secondary detection.

\section{Image analysis}

Image analyses of histological and immunohistological sections were conducted on digitally captured sections as previously described (Ogborn et al. 1998, 2000, 2005). Cyst area was quantified using a $20 \times$ objective to determine the proportion of section areas that were occupied by cysts. Using a $40 \times$ objective, the fractions of image area stained for fibrosis and oxidized LDL and for the number of cells positive for macrophages and proliferating cell nuclear antigen were quantified and expressed relative to solid tissue area, thereby correcting for the extent of cystic change in each kidney. 


\section{Biochemistry}

Serum urea was determined spectrophotometrically using reagents from Sigma kit 640A (Sigma Chemical Co., St. Louis, MO, USA). Serum creatinine and urinary creatinine were measured using the method developed by Heinegard \& Tiderstrom (1973) and urinary protein was measured using the Bradford method for total protein (Bradford, 1976). Standards and reagents for these assays were from Sigma.

\section{Statistical analysis}

Data were analysed by two-way (feeding period, treatment diet) ANOVA, followed by post-hoc $t$ tests if there was a significant interaction between main effects, using Statistical Analysis Systems statistical software package version 8 (SAS, Cary, NC, USA). Post-hoc $t$ tests were also used to compare simple effects when both main effects were significant in order to determine whether the effects of the soya protein diet were different in the weaning period compared with the maternal period. Normality of the data was tested using a plot of residuals $v$. predicted, as well as the Shapiro-Wilk's W statistic. If necessary, data were normalized by logarithmic transformation. Differences in main effects or interactions were considered significant if $P<0 \cdot 05$.

\section{Results}

Rats grew equally well in all treatments, as evidenced by the similar body weights at weaning and at the end of the study (Table 2). There also was no difference in food or water intake (data not shown), indicating that the level of protein intake was not different among rats in all treatments. Consistent with previous studies in this model, soya protein substitution for casein in the weaning period resulted in significant reductions in disease progression. Cyst growth, renal inflammation, renal oxidative damage, renal cell proliferation, serum creatinine and serum urea were lower, and creatinine clearance was higher in rats given soya protein in the weaning period (Tables 2 and 3).

Soya protein compared with casein in the maternal period resulted in $24 \%$ less renal inflammation as shown by a reduction in macrophage infiltration (Table 3, Fig. 1). In the weaning period soya protein reduced macrophage infiltration by $32 \%$. When it was included during both time periods, there was $48 \%$ less macrophage infiltration compared with when casein was the dietary protein source. In order to determine whether the effect of soya protein in both dietary periods was significantly different than when present only in either the maternal or weaning periods, post hoc $t$ tests were performed. These analyses revealed that macrophage counts were significantly lower in rats given soya protein during both maternal and weaning periods, compared with when soya protein was given in only one of these time periods. There was no difference in the macrophage counts when soya was given in the maternal compared with weaning period alone, but counts were lower in either case compared with when soya protein was not present in any period.

Oxidative damage in the diseased kidneys was $28 \%$ lower in rats when soya protein was given in the maternal period and $56 \%$ lower when given during the weaning period (Table 3, Fig. 2).

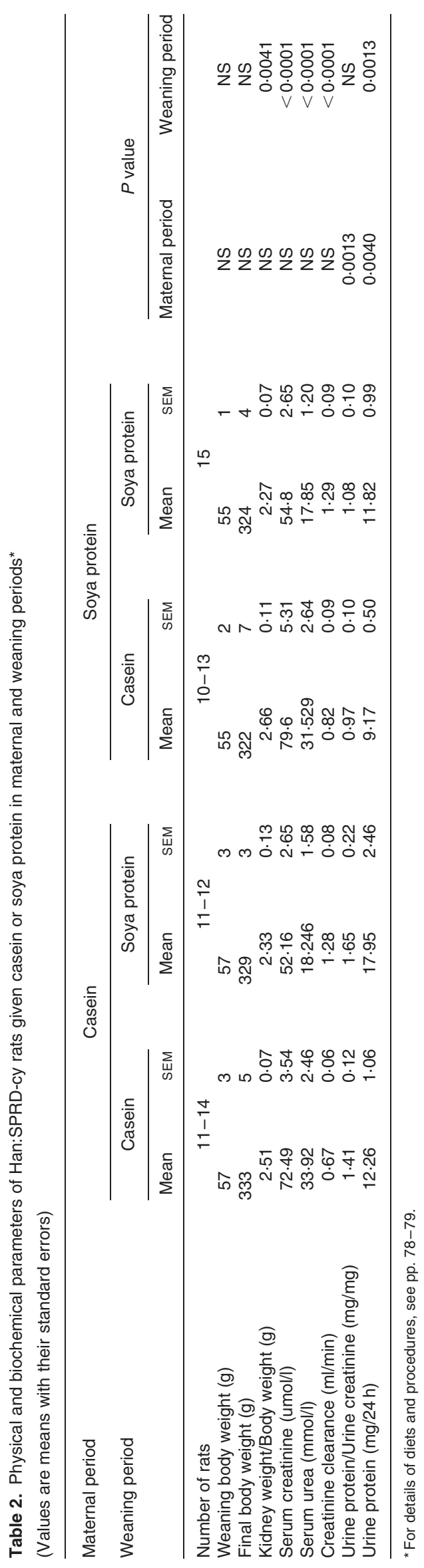


The combined effect of a soya-based diet in both the maternal and weaning periods resulted in $60 \%$ less oxidative damage than when casein was given as the dietary protein source. In this case, post-hoc analyses revealed that while soya protein compared with casein in both the maternal or weaning period resulted in less oxidized LDL staining, soya protein given in the weaning period was more effective than in the maternal period. The combination of dietary soya protein in the maternal and weaning periods was not significantly different than including soya protein in the weaning period alone.

For estimation of cell proliferation, there was an interaction between the feeding periods and diet treatments. Cell proliferation in kidneys was lower when soya protein was included in either feeding period, but the results were not additive. Proliferating cell nuclear antigen counts were 29-33\% lower when soya protein was included in either or both feeding periods (Table 3, Fig. 3).

With regard to renal function, the parameters that were influenced by soya protein in the weaning period (serum creatinine, urea and creatinine clearance) were not affected by soya in the maternal period. However, soya protein compared with casein in the maternal period did result in less proteinuria (Table 2), whether expressed per $24 \mathrm{~h}$ excretion ( $29 \%$ lower) or when corrected to creatinine excretion (33\% lower). Soya protein in the weaning period resulted in higher proteinuria when expressed on a $24 \mathrm{~h}$ basis, but not when corrected to creatinine.

\section{Discussion}

In addition to confirming the protective effects of dietary soya protein compared with casein in the weaning period of rodents with cystic kidney diseases (Ogborn et al. 1998, 2000; Aukema \& Housini, 2001; Fair et al. 2004), the present study demonstrates that dietary soya protein in the maternal period also positively influences renal disease progression in offspring with congenital kidney disease. Such findings fit into a growing body of knowledge that supports the Fetal Origins of Adult Diseases hypothesis or the so-called fetal programming effect, in which nutrient intake during the perinatal period correlates to the risk of chronic disease development later in life. Recent studies demonstrate that maternal malnutrition can have detrimental effects on the kidney, such as a reduction in nephron number and the development of hypertension in offspring later in life (Langley-Evans et al. 1999; Barker \& Bagby, 2005; Vehaskari \& Woods, 2005). The current study reflects a unique concept, in that soya protein in the maternal period has a positive effect on disease progression, demonstrating the potential for dietary interventions during the maternal period to counter the development and progression of disease. This also has been observed in cancer models that are characterized by inflammation and increased proliferation, as colon tumorigenesis and mammary cancer are reduced in the offspring of rats given dietary soya protein or genistein (Fritz et al. 1998; Linz et al. 2004).

Interestingly, the effects of soya protein in the maternal period are similar to the effects of soya protein in the weaning period in some parameters (inflammation, oxidized damage, proliferation), but not in others (cystic change, serum urea, creatinine and creatinine clearance). In addition to the independent (main) effects of soya protein on inflammation and oxidized damage in the maternal feeding, soya protein 

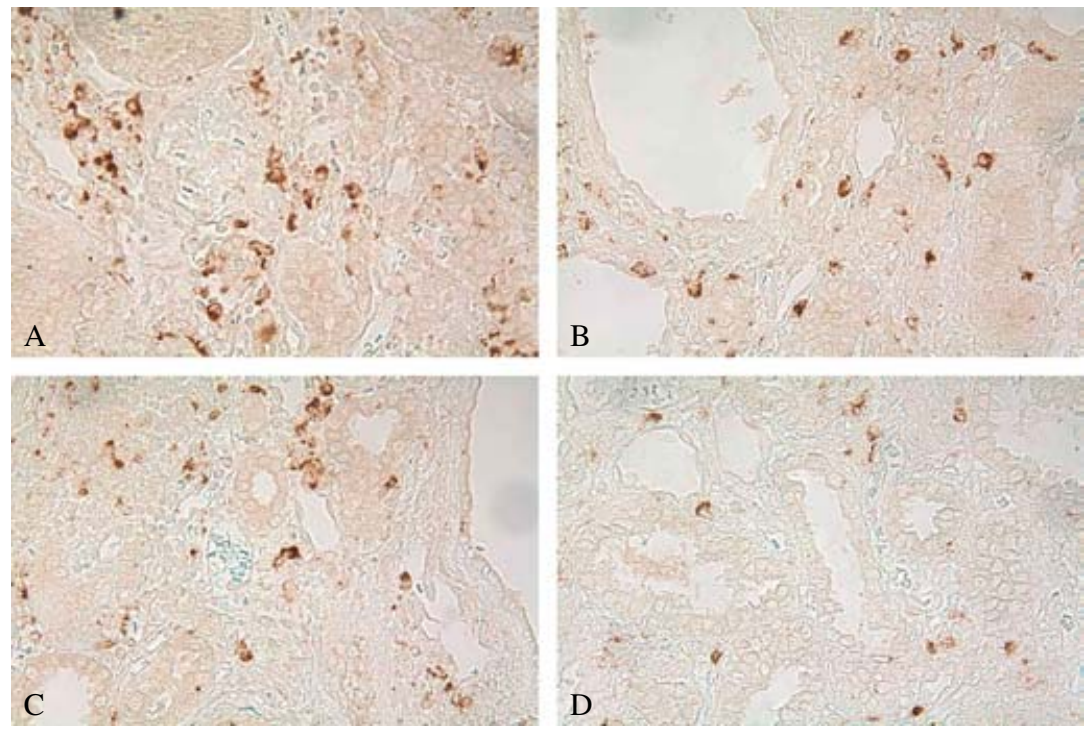

Fig. 1. Renal macrophage infiltration (mouse anti-rat MAB 1435 antibody, 1:50 dilution, $\times 40$ magnification.) in kidney sections from 10-week-old animals given (A) casein in maternal and weaning periods; (B) casein in maternal period and soya protein in weaning period; (C) soya protein in maternal period and casein in weaning period; (D) soya protein in maternal and weaning periods. For details of diets and procedures, see pp. $78-79$.

in the maternal compared with the weaning period also uniquely resulted in less proteinuria. A reduction in urinary protein and albumin excretion with soya protein intake has also been reported in both animal models and human subjects with nephropathy (Teixeira et al. 2003, 2004; Stephenson et al. 2005). It is possible that the effect of soya protein on proteinuria that we observed is due to differences in protein reabsorption secondary to differences in the rate of progression of cyst formation on account of the perinatal interventions. Long-term studies are needed to determine whether these apparent beneficial effects on renal pathology and function would result in delayed disease progression and postponed renal failure over time.
In a recent study of Han:SPRD-cy rats given purified genistein for 8 weeks, macrophage infiltration and staining for oxidized LDL were reduced (Ogborn et al. 2005). These are the two histological parameters for which there was a significant main effect of soya protein given during the maternal period in the current study. Interestingly, neither dietary genistein in the weaning period in the aforementioned study (Ogborn et al. 2005) nor soya protein in the maternal period in the current study affected serum creatinine, kidney size or cyst growth. The lack of an effect of genistein on serum creatinine, kidney size and kidney water content (reflecting cyst growth) was also observed in another model of renal cyst disease, the pcy mouse, in which dietary soya protein has been shown to
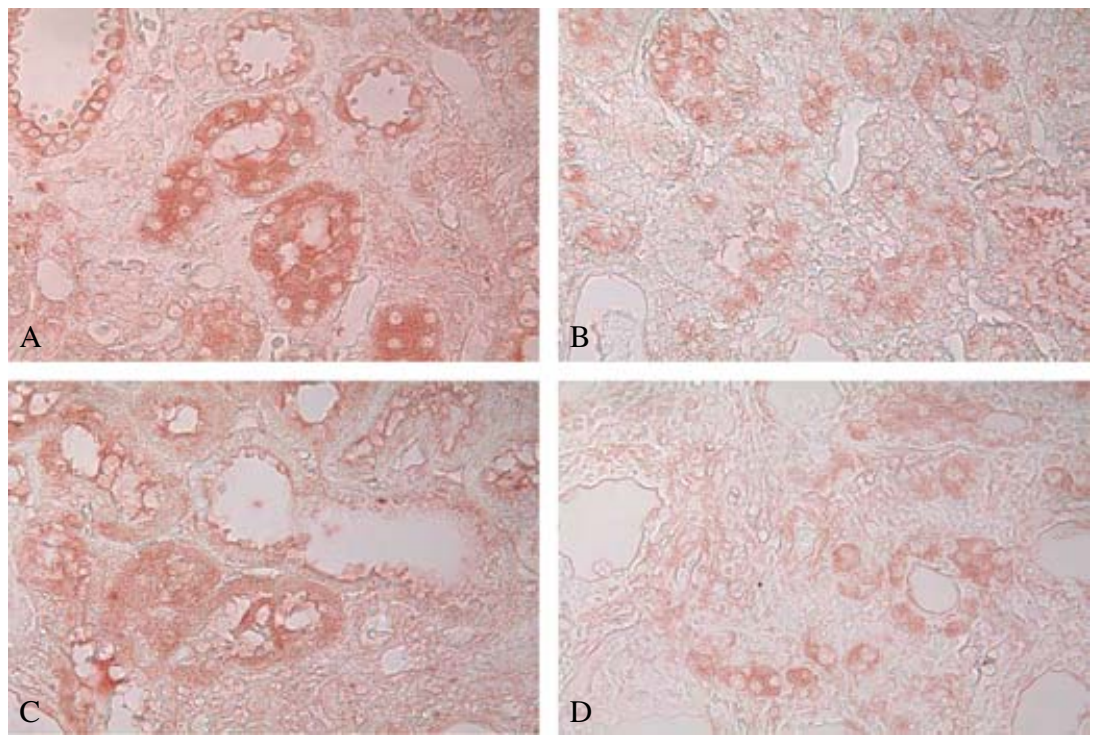

Fig. 2. Oxidized LDL staining (rabbit anti-Cu2 + -oxidized LDL polyclonal antibody, 1:50 dilution, $\times 40$ magnification) in kidney sections from 10-week-old animals given (A) casein in maternal and weaning periods; (B) casein in maternal period and soya protein in weaning period, (C) soya protein in maternal period and casein in weaning period; (D) soya protein in maternal and weaning periods. For details of diets and procedures, see pp. 78-79. 

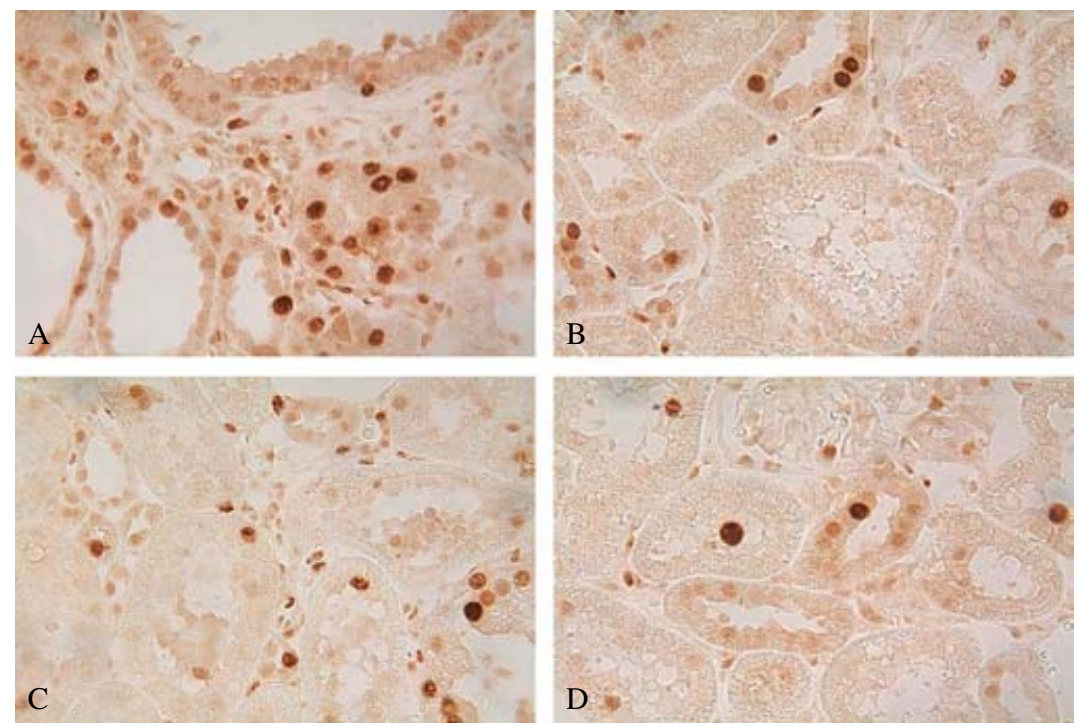

Fig. 3. Proliferating cell nuclear antigen staining (anti-mouse proliferating cell nuclear antigen antibody, 1:50 dilution, $\times 40$ magnification) in kidney sections from 10-week-old animals given (A) casein in maternal and weaning periods; (B) casein in maternal period and soya protein in weaning period; (C) soya protein in maternal period and casein in weaning period; (D) soya protein in maternal and weaning periods. For details of diets and procedures, see pp. 78-79.

slow disease progression (Tomobe et al. 1998). In contrast, the soya protein given in the weaning period of the current study did affect these parameters, as previously shown (Ogborn et al. 1998, 2000; Aukema \& Housini, 2001; Fair et al. 2004). Therefore, the effects of soya protein on disease progression are likely due to several components in the diet and the difference in effects of dietary soya protein in the maternal compared with the weaning periods suggests different mechanisms of action of soya protein at different life stages.

The effects of soya protein as inhibitor of cell proliferation may be due to the oestrogen-like activity of isoflavones (such as genistein) found in soya protein, as the isoflavones and their metabolites have oestrogen receptor-binding ability, particularly for the oestrogen receptor- $\beta$ (Branham et al. 2002; Setchell et al. 2005). The possible oestrogen-like effect is of interest because the progression of cystic disease in the Han:SPRD-cy rat model displays a strong sexual dimorphism (Cowley et al. 1993), a phenomenon also observed to a lesser extent in human subjects with cystic renal diseases (Choukroun et al. 1995). Castration of male Han:SPRD-cy rats slows renal disease progression, and the administration of testosterone to females or castrated males increases cystic development (Cowley et al. 1997). Gender also influences the effect of soya protein on disease progression in this model as well as the pcy mouse (Aukema et al. 1999; Aukema \& Housini, 2001). The anti-proliferative effect of soya protein is unlikely to be solely due to genistein, as the concentrations that exhibit in vitro effects on protein tyrosine kinases and DNA topoisomerases are not likely to be achieved in vivo with dietary soya protein (Akiyama et al. 1987; Markovits et al. 1989). A contributory effect of genistein on the reduction of proliferation observed cannot be ruled out, however. Possibly supporting a role for genistein in this regard is a recent study, which reported that kidney weight was reduced in 21-d-old female offspring of mice given genistein during pregnancy and lactation (Ryokkynen et al. 2005).

Another potential phyto-oestrogenic effect may be the generation of NO (Trujillo et al. 2005). NO levels are low in patients with chronic renal disease and have been reported to be down regulated in the Han:SPRD-cy rat, suggesting that NO metabolism is associated with the progression of renal disease (Hwang et al. 2003). Renal protection by a soya diet in obese Zucker rats is associated with restoration of $\mathrm{NO}$ generation (Wang et al. 2004). NO plays an important role in regulating placental-fetal blood flow, influencing the transfer of nutrients and $\mathrm{O}_{2}$ from mother to fetus (Lillycrop et al. 2005).

The differing amino acid content of soya protein compared with casein also may have mediated the effects observed in the current study. Dietary vegetable protein compared with animal protein appears to be associated with lower plasma levels of lysine and valine; the latter is correlated with glomerular filtration rate (Regnault et al. 2005). An increased glomerular filtration rate may cause intraglomerular hypertension, which leads to the progressive loss of renal function (Hostetter, 2003). It remains to be determined whether or not early exposure to an amino acid profile that decreases hyperfiltration responses contributes to the protective effect of soya protein in renal disease. Soya protein compared with casein also contains twice as much of the amino acids arginine and glycine (Fair et al. 2004). Arginine is a substrate for polyamine, NO and proline synthesis and as such may improve fetal health. Arginine and arginine-family amino acids recently have been discovered to be abundant in ovine and porcine allantoic fluids, indicating their importance in fetal development (Lillycrop et al. 2005). With regard to glycine, supplementation of a protein-restricted gestational diet with glycine reverses the increase in systolic blood pressure that occurs in the offspring of protein-restricted dams (Jackson et al. 2002). Maternal protein restriction is known to negatively impact kidney function by reducing nephron number and result in hypertension in offspring (Langley-Evans et al. 1999).

The results of the current study establish the importance of maternal nutrition in offspring with genetically determined renal diseases. Since approximately one in 500 to 1000 people inherit a form of renal cyst disease, the influence of 
maternal nutrition on the progression of these diseases is significant. The exact mechanism(s) by which maternal dietary soya protein attenuates kidney disease in offspring remain to be determined. However, this work may have application to populations with a high prevalence of renal disease attributed to early life programming, as may be the case in some aboriginal populations (Zandi-Nejad et al. 2006).

\section{Acknowledgements}

This study was supported by grants from The Natural Science and Engineering Research Council of Canada and The Manitoba Institute of Child Health, a division of the Children's Hospital Foundation of Manitoba Inc. The authors wish to thank Evan Nitschmann, Kari Hamblin and Ling Lee for their technical assistance in this study.

\section{References}

Akiyama T, Ishida J, Nakagawa S, Ogawara H, Watanabe S, Itoh N, Shibuya M \& Fukami Y (1987) Genistein, a specific inhibitor of tyrosine-specific protein kinases. J Biol Chem 262, 5592-5595.

American Institute of Nutrition (1993) AIN-93 purified diets for laboratory rodents: final report of the American Institute of Nutrition ad hoc writing committee on the reformulation of the AIN-76A rodent diet. J Nutr 123, 1939-1951.

Aukema HM \& Housini I (2001) Dietary soy protein effects on disease and IGF-I in male and female Han:SPRD-cy rats. Kidney Int 59, 52-61.

Aukema HM, Housini I \& Rawling JM (1999) Dietary soy protein effects on inherited polycystic kidney disease are influenced by gender and protein level. J Am Soc Nephrol 10, 300-308.

Azadbakht L, Shakerhosseini R, Atabak S, Jamshidian M, Mehrabi Y \& Esmaill-Zadeh A (2003) Beneficiary effect of dietary soy protein on lowering plasma levels of lipid and improving kidney function in type II diabetes with nephropathy. Eur J Clin Nutr 57, 1292-1294.

Barker DJ \& Bagby SP (2005) Developmental antecedents of cardiovascular disease: a historical perspective. J Am Soc Nephrol 16, 2537-2544.

Barsotti G, Morelli E, Cupisti A, Bertoncini P \& Giovannetti S (1991) A special, supplemented 'vegan' diet for nephrotic patients. Am J Nephrol 11, 380-385.

Bradford M (1976) A rapid and sensitive method for the quantitation of microgram quantities of protein utilizing the principle of protein-dye binding. Anal Biochem 72, 248-254.

Branham WS, Dial SL, Moland CL, Hass BS, Blair RM, Fang H, Shi L, Tong W, Perkins RG \& Sheehan DM (2002) Phytoestrogens and mycoestrogens bind to the rat uterine estrogen receptor. $J$ Nutr 132, 658-664.

Bosch J, Saccaggi A, Lauer A, Ronco C, Belledonne M \& Glabman S (1983) Renal functional reserve in humans. Effect of protein intake on glomerular filtration rate. Am J Med 75, 943-950.

Chen S, Peng S \& Chen J (2003) Effects of dietary protein on renal function and lipid metabolism in five-sixths nephrectomized rats. Brit J Nutr 133, 673-678.

Choukroun G, Itakura Y, Albouze G, Christophe JL, Man NK, Grunfeld JP \& Jungers P (1995) Factors influencing progression of renal failure in autosomal dominant polycystic kidney disease. J Am Soc Nephrol 6, 1634-1642.

Cowley BD Jr, Gudapaty S, Kraybill AL, Barash BD, Harding MA, Calvet JP \& Gattone VH 2nd (1993) Autosomal-dominant polycystic kidney disease in the rat. Kidney Int 43, 522-534.

Cowley BD Jr, Rupp JC, Muessel MJ \& Gattone VH 2nd (1997) Gender and the effect of gonadal hormones on progression of inherited polycystic kidney disease in rats. Am J Kidney Dis 29, $265-272$.

D’Amico G, Remuzzi G, Maschio G, Gentile MG, Gotti E, Oldrizzi L, Manna G, Mecca G, Rugiu C \& Fellin G (1991) Effects of dietary proteins and lipids in patients with membranous nephrology and nephrotic syndrome. Clin Nephrol 6, 237-242.

Fair DE, Ogborn MR, Weiler HA, Bankovic-Calic N, Nitschmann EP, Fitzpatrick-Wong SC \& Aukema HM (2004) Dietary soy protein attenuates renal disease progression after 1 and 3 weeks in Han:SPRD-cy weanling rats. J Nutr 134, 1504-1507.

Fritz WA, Coward L, Wang J \& Lamartiniere CA (1998) Dietary genistein: perinatal mammary cancer prevention, bioavailability and toxicity testing in the rat. Carcinogenesis 19, 2151-2158.

Gentile M, Fellin G, Cofano F, Delle Fave A, Manna G, Ciceri R, Petrini C, Lavarda F, Pozzi F \& D'Amico G (1993) Treatment of proteinuric patients with vegetarian soy diet and fish oil. Clin Nephrol 40, 315-320.

Gretz N, Ceccherini I, Kranzlin B, Kloting I, Devoto M, Rohmeiss P, Hocher B, Waldherr R \& Romeo G (1995) Gender-dependent disease severity in autosomal polycystic kidney disease of rats. Kidney Int 48, 496-500.

Heinegard D \& Tiderstrom G (1973) Determination of serum creatinine by a direct colorimetric method. Clin Chim Acta 43, $305-310$.

Hostetter T (2003) Prevention of the development and progression of renal disease. J Am Soc Nephrol 14, S144-S147.

Hwang J, Wang J, Morazzoni P, Hodis HN \& Sevanian A (2003) The phytoestrogens equol increases nitric oxide availability by inhibiting superoxide production: an antioxidant mechanism for cell mediated LDL modification. Free Radic Biol Med 34, 1271-1282.

Iwasaki K, Gleiser CA, Masoro EJ, McMahan CA, Seo EJ \& Yu BP (1988) The influences of dietary soy protein on longevity and agerelated disease processes of Fischer rats. J Gerontol 43, B5-B12.

Jackson AA, Dunn RL, Marchand MC \& Langley-Evans SC (2002) Increased systolic blood pressure in rats induced by a maternal low-protein diet is reversed by dietary supplementation with glycine. Clin Sci (Lond) 103, 633-639.

Jibani MM, Bloodworth LL, Foden E, Griffiths KD \& Galpin OP (1991) Predominantly vegetarian diet in patients with incipient and early clinical diabetic nephropathy: effects on albumin excretion rate and nutritional status. Diabet Med 8, 949-953.

Knight E, Stampfer M, Hankinson S, Spiegelman D \& Curhan G (2003) The impact of protein on renal function decline in women with normal renal function or mild renal insufficiency. Ann Intern Med 138, 460-467.

Kontessis P, Jones S, Dodds R, Trevisan R, Nosadini R, Fioretto P, Borsato M, Sacerdoti D \& Viberti G (1990) Renal, metabolic and hormonal responses to ingestion of animal and vegetable proteins. Kidney Int 38, 136-144.

Langley-Evans SC, Welham SJM \& Jackson AA (1999) Fetal exposure to a maternal low protein diet impairs nephrogenesis and promotes hypertension in the rat. Life Sci 64, 965-974.

Lillycrop KA, Phillips ES, Jackson AA, Hanson MA \& Burdge GC (2005) Dietary protein restriction of pregnant rats induces and folic acid supplementation prevents epigenetic modification of hepatic gene expression in the offspring. J Nutr 135, 1382-1386.

Linz AL, Xiao R, Parker JG, Simpson PM, Badger TM \& Simmen FA (2004) Feeding of soy protein isolate to rats during pregnancy and lactation suppresses formation of aberrant crypt foci in their progeny's colons: interaction of diet with fetal alcohol exposure. J Carcinog 3, 14-28.

Markovits J, Linassier C, Fosse P, Couprie J, Pierre J, JacqueminSablon A, Saucier JM, Le Pecq JB \& Larsen AK (1989) Inhibitory effects of the tyrosine kinase inhibitor genistein on mammalian DNA topoisomerase II. Cancer Res 49, 5111-5117.

Meguid El Nahas A \& Bello AK (2005) Chronic kidney disease: the global challenge. Lancet 365, 331-340. 
Ogborn MR, Bankovic-Calic N, Shoesmith C, Buist R \& Peeling J (1998) Soy protein modification of rat polycystic kidney disease. Am J Physiol 274, F541-F549.

Ogborn MR, Nitschmann E, Bankovic-Calic N, Weiler H \& Aukema H (2005) Flax and soy phytoestrogen effects on renal injury and lipid content in experimental polycystic kidney disease. $J$ Am Nutraceut Assoc 8, 26-32.

Ogborn MR, Nitschmann E, Weiler HA \& Bankovic-Calic N (2000) Modification of polycystic kidney disease and fatty acid status by soy protein diet. Kidney Int 57, 159-166.

Pedraza-Chaverri J, Barrera D, Hernandez-Pando R, Medina-Campos ON, Cruz C, Murguia F, Juarez-Nicolas C, Correa-Rotter R, Torres N \& Tovar AR (2004) Soy protein diet ameliorates renal nitrotyrosine formation and chronic nephropathy induced puromycin aminonucleoside. Life Sci 74, 987-999.

Regnault TR, Friedman JE, Wilkening RB, Anthony RV \& Hay WW Jr (2005) Fetoplacental transport and utilization of amino acids in IUGR - a review. Placenta 19, S52-S62.

Ryokkynen A, Kukkonen JV \& Nieminen P (2005) Effects of dietary genistein on mouse reproduction, postnatal development and weight-regulation. Anim Reprod Sci 93, 337-348.

Setchell KD, Clerici C, Lephart ED, et al. (2005) S-equol, a potent ligand for estrogen receptor beta, is the exclusive enantiomeric form of the soy isoflavone metabolite produced by human intestinal bacterial flora. Am J Clin Nutr 81, 1072-1079.

Stephenson TJ, Setchell KD, Kendall CW, Jenkins DJ, Anderson JW \& Fanti P (2005) Effect of soy protein-rich diet on renal function in young adults with insulin-dependent diabetes mellitus. Clin Nephrol 64, 1-11.

Teixeira S, Tappeneden K, Carson L, Jones R, Prabhudesai K, Marshell W \& Erdman J Jr (2004) Isolated soy protein consumption reduces urinary albumin excretion and improves the serum lipid profile in men with type 2 Diabetes Mellitus and nephropathy. J Nutr 134, 1874-1880.

Teixeira S, Tappenden K \& Erdman J (2003) Altering dietary protein type and quantity reduces urinary albumin excretion without affecting plasma glucose concentration in BKS.cg-m + Lepr $\mathrm{db}(\mathrm{db} / \mathrm{db})$ mice. J Nutr 133, 673-678.

Tomobe K, Philbrick DJ, Ogborn MR, Takahashi H \& Holub BJ (1998) Effect of dietary soy protein and genistein on disease progression in mice with polycystic kidney disease. Am J Kidney Dis 31, 55-61.

Trujillo J, Ramirez V, Perez J, Torre-Villalvazo I, Torres N, Tovar AR, Munoz RM, Uribe N, Gamba G \& Bobadilla NA (2005) Renal protection by a soy diet in obese Zucker rats is associated with restoration of nitric oxide generation. Am J Physiol Renal Physiol 288, F108-F116.

Vehaskari VM \& Woods LL (2005) Prenatal programming of hypertension: lessons from experimental models. J Am Soc Nephrol 16, $2545-2556$.

Wang D, Braendstrup O, Larsen S, Horn T \& Strandgaard S (2004) The expression and activity of renal nitric oxide synthase and circulating nitric oxide in polycystic kidney disease rats. APMIS 112, 358-368.

Williams A \& Wallis J (1987a) Metabolic consequences of differing protein diets in experimental renal disease. Eur J Clin Invest 17, 117-122.

Williams A \& Wallis J (1987b) Effect of varying quantity and quality of dietary protein intake in experimental renal disease in rats. Nephron 46, 83-90.

Zerres K, Volpel MC \& Weiss H (1984) Cystic kidneys: genetics, pathologic anatomy, clinical picture, and prenatal diagnosis. Hum Genet 68, 104-135.

Zandi-Nejad K, Luyckx VA \& Brenner BM (2006) Adult hypertension and kidney disease: the role of fetal programming. Hypertension 47, 502-508. 